\section{Structure of Aspochalasin H, a New Member of the Aspochalasin Family}

\author{
Taijiro Tomikawa, Kazuo Shin-ya, Haruo Seto, \\ NORIYUKI OKUSA ${ }^{a}$, TAKAYUKI KaJIURA ${ }^{a}$ and \\ YOICHI HAYAKAWA*
}

Institute of Molecular and Cellular Biosciences, The University of Tokyo,

Bunkyo-ku, Tokyo 113-0032, Japan

a Pharmaceutical Research Laboratories, Ajinomoto Co., Inc., Suzuki-cho, Kawasaki, Kanagawa 210-8681, Japan

(Received for publication April 30, 2002)

We previously reported that aspochalasin $\mathrm{D}^{1)}$ showed selective cytotoxicity against ras-dependent $\mathrm{Ba} / \mathrm{F} 3$ cells $^{2)}$. In this paper, we describe the structure of aspochalasin $\mathrm{H}$ (Fig. 1), a new member of the aspochalasin family produced by the aspochalasin D-producing strain, Aspergillus sp. AJ117509.

The fermentation was carried out in 500-ml Erlenmeyer flasks containing $100 \mathrm{ml}$ of a medium consisting of soluble starch $3.0 \%$, sucrose $1.0 \%$, Pharmamedia $1.0 \%$, Polypepton $0.5 \%$ Distiller's soluble $0.5 \%, \mathrm{MgSO}_{4} 0.05 \%, \mathrm{CaCO}_{3} 0.3 \%$ and $\mathrm{NaCl} 0.1 \%(\mathrm{pH} 6.0)$ on a rotary shaker at $25^{\circ} \mathrm{C}$ for 6 days. The butanol extract of the culture (2 liters) was evaporated to an aqueous concentrate and then partitioned between EtOAc and $\mathrm{H}_{2} \mathrm{O}$. The organic layer was subjected to silica gel column chromatography with $\mathrm{CHCl}_{3}-\mathrm{MeOH}$ $(20: 1)$. The eluate was purified by HPLC using a SenshuPak PEGASIL ODS column with $65 \% \mathrm{MeOH}$. The purified fraction was concentrated to dryness to give a colorless powder $(4.8 \mathrm{mg})$ of aspochalasin $\mathrm{H}$.

The molecular formula of aspochalasin $\mathrm{H}$ was established to be $\mathrm{C}_{24} \mathrm{H}_{35} \mathrm{NO}_{5}$ by high-resolution FAB-MS. The ${ }^{13} \mathrm{C}$ and ${ }^{1} \mathrm{H}$ NMR spectra of aspochalasin $\mathrm{H}$ exhibited 24 carbon and 35 proton signals (Table 1). A heteronuclear multiple-quantum coherency $(\mathrm{HMQC})^{3)}$ experiment established ${ }^{1} \mathrm{H}-{ }^{13} \mathrm{C}$ one-bond connectivities as shown in Table 1. A COSY experiment revealed three spin networks to generate partial structures $\mathbf{A}$ to $\mathbf{C}$ (Fig. 2). Proton and carbon chemical shifts for 19- and 20-positions and their vicinal coupling constant $(1.5 \mathrm{~Hz})$ assigned this part to a trans epoxide moiety. The heteronuclaer multiple-bond correlation $\left.(\mathrm{HMBC})^{4}\right)$ spectrum of aspochalasin $\mathrm{H}$ displayed ${ }^{1} \mathrm{H}-{ }^{13} \mathrm{C}$ long-range couplings from $12-\mathrm{H}_{3}$ to $\mathrm{C}-5$, C-6 and $\mathrm{C}-7$, and from $25-\mathrm{H}_{3}$ to $\mathrm{C}-13, \mathrm{C}-14$ and $\mathrm{C}-15$, indicating the connections between partial structures $\mathbf{A}$ and $\mathbf{B}$ via $\mathbf{C}-6$, and between $\mathbf{B}$ and $\mathbf{C}$ via $\mathrm{C}-14$ as shown in Fig. 2. A ketone carbonyl (C-21) revealed long-range couplings from $19-\mathrm{H}$ and $20-\mathrm{H}$, and was required to be joined to $\mathrm{C}$ 20. ${ }^{1} \mathrm{H}-{ }^{13} \mathrm{C}$ long-range correlations from $4-\mathrm{H}$ to an amide carbonyl (C-1) and a quaternary carbon (C-9) showed the presence of a $\gamma$-lactam ring. In the remaining connectivities, each C-8, C-9 and C-21 required additional carbon-carbon bonds from their chemical shifts, indicating that C-8 and C-21 were connected with C-9. The geometrical configuration of $\mathrm{C}-13$ was determined to be $E$ based on an upfield chemical shift for C-25 and an NOE between $8-\mathrm{H}$ and $25-\mathrm{H}_{3}$. A NOESY experiment exhibited NOEs between $5-\mathrm{H}$ and $8-\mathrm{H}$, between $4-\mathrm{H}$ and $10-\mathrm{H}$, and between $3-\mathrm{H}$ and $11-\mathrm{H}$, indicating $\beta$ configurations for $4-\mathrm{H}$, 5-H and 8-H, and an $\alpha$ configuration for 3-H (Fig. 3). An

Fig. 1. Structures of aspochalasins D and H.

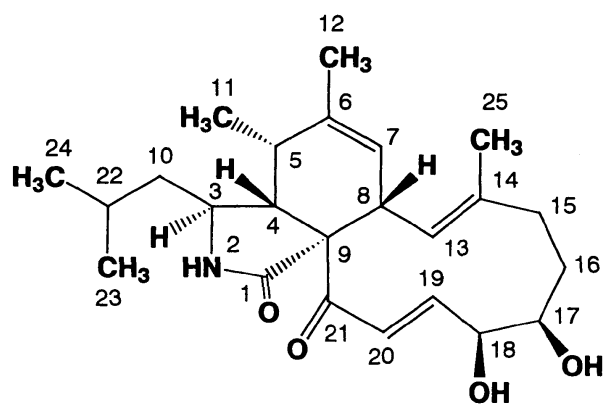

Asopochalasin D

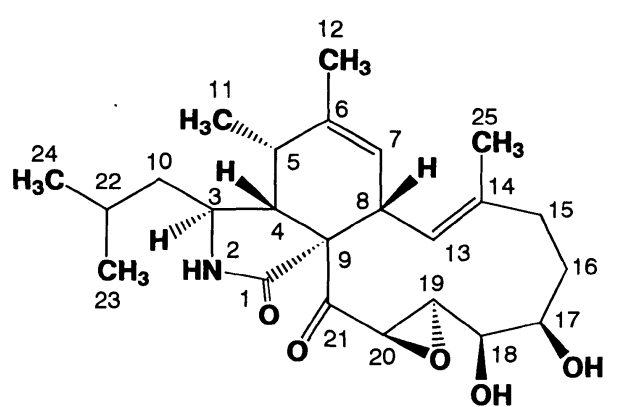

Aspochalasin $\mathrm{H}$

* Corresponding author: hayakawa@iam.u-tokyo.ac.jp 
Table 1. ${ }^{13} \mathrm{C}(125 \mathrm{MHz})$ and ${ }^{1} \mathrm{H}(500 \mathrm{MHz})$ NMR assignments for aspochalasin $\mathrm{H}$ in $\mathrm{CDCl}_{3}$.

\begin{tabular}{rrlrrl}
\hline No. & $\delta_{\mathrm{c}}$ & $\delta_{\mathrm{H}}$ (multiplicity, $\left.J=\mathrm{Hz}\right)$ & No. & $\delta_{\mathrm{c}}$ & $\delta_{\mathrm{H}}$ (multiplicity, $\left.J=\mathrm{Hz}\right)$ \\
\hline 1 & 174.6 & & 14 & 136.0 & \\
2 & & $6.06($ broad s) & 15 & 38.9 & $2.25(\mathrm{t}, 13.0)$ \\
3 & 51.7 & $3.08(\mathrm{dt}, 10.0,3.5)$ & & & $2.11(\mathrm{~m})$ \\
4 & 52.8 & $2.64(\mathrm{~d}, 3.5)$ & 16 & 29.3 & $2.12(\mathrm{~m})$ \\
5 & 35.4 & $2.58(\mathrm{~m})$ & & & $1.53(\mathrm{~m})$ \\
6 & 140.7 & & 17 & 72.9 & $4.04(\mathrm{~s})$ \\
7 & 125.5 & $5.38(\mathrm{~m})$ & 18 & 78.4 & $3.37(\mathrm{~d}, 7.0)$ \\
8 & 44.1 & $3.02(\mathrm{~d}, 11.0)$ & 19 & 61.7 & $2.62(\mathrm{dd}, 7.0,1.5)$ \\
9 & 67.4 & & 20 & 54.7 & $4.19(\mathrm{~d}, 1.5)$ \\
10 & 48.6 & $1.29(\mathrm{~m})$ & 21 & 205.6 & \\
& & $1.19(\mathrm{~m})$ & 22 & 25.2 & $1.53(\mathrm{~m})$ \\
11 & 13.7 & $1.19(3 \mathrm{H}, \mathrm{d}, 7.0)$ & 23 & 23.6 & $0.90(3 \mathrm{H}, \mathrm{d}, 6.0)$ \\
12 & 20.1 & $1.75(3 \mathrm{H}, \mathrm{s})$ & 24 & 21.2 & $0.88(3 \mathrm{H}, \mathrm{d}, 6.0)$ \\
13 & 124.6 & $5.98(\mathrm{~d}, 11.0)$ & 25 & 15.5 & $1.42(3 \mathrm{H}, \mathrm{s})$ \\
& & & & & \\
\hline
\end{tabular}

Fig. 2. COSY and HMBC data summary for aspochalasin $\mathrm{H}$.

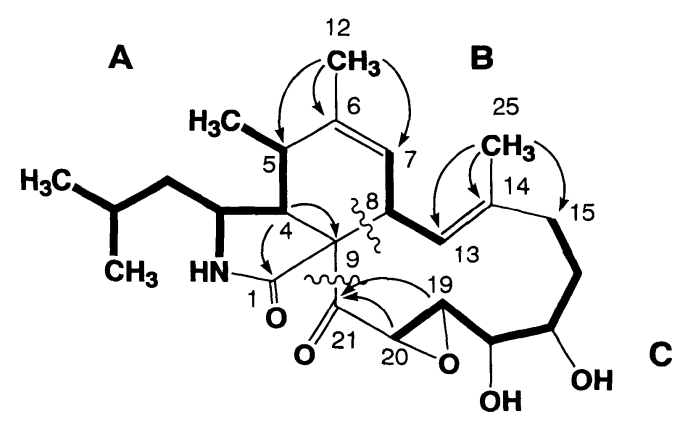

Bold lines show proton spin networks and arrows indicate ${ }^{1} \mathrm{H}-{ }^{13} \mathrm{C}$ long-range couplings.

NOE between $8-\mathrm{H}$ and $19-\mathrm{H}$ showed that the ketone carbonyl (C-21) was oriented to the $\beta$ side. NOEs between $8-\mathrm{H}, 19-\mathrm{H}$ and $25-\mathrm{H}_{3}$ required these protons to be on the $\beta$ side of the 11-membered ring. On the other hand, NOEs from $18-\mathrm{H}$ to $17-\mathrm{H}$ and $20-\mathrm{H}$, and from $13-\mathrm{H}$ to $17-\mathrm{H}$ revealed their $\alpha$ orientations. The cis configuration for the diol moiety was supported by a small coupling constant $(<1 \mathrm{~Hz})$ between $17-\mathrm{H}$ and $18-\mathrm{H}$. The relative stereochemistry of aspochalasin $\mathrm{H}$ thus obtained was
Fig. 3. Relative stereochemistry of aspochalasin $\mathrm{H}$ revealed by a NOESY experiment.

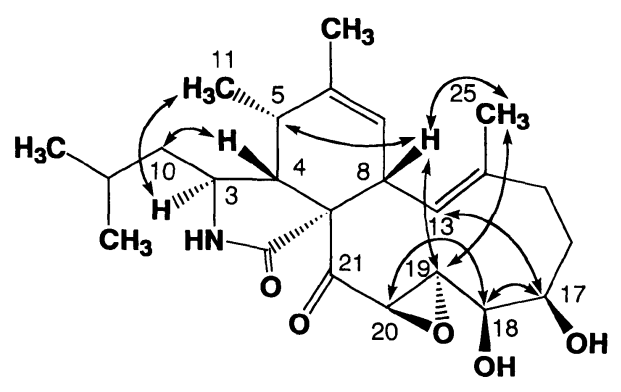

identical with that of aspochalasin $\mathrm{D}^{2)}$.

Aspochalasin $\mathrm{H}$ did not show cytotoxity against rasdependent $\mathrm{Ba} / \mathrm{F} 3$ cells at less than $25 \mu \mathrm{g} / \mathrm{ml}$, whereas aspochalasin $\mathrm{D}$ induced cell death with an $\mathrm{IC}_{50}$ of $0.49 \mu \mathrm{g} / \mathrm{ml}$. The carbonyl-conjugated olefin at C-19 appeared to be significant for cytotoxicity of the aspochalasins.

\section{Acknowledgment}

This work was supported in part by Research for the Future, Japan Society for Promotion of Science and a Grant-in-Aid for 
Scientific Research on Priority Areas, The Ministry of Education, Culture, Sports, Science and Technology, Japan.

\section{References}

1) Keller-Schierlein, W. \& E. Kupfer: Stoffwechselprodukte von Mikroorganismen. Über die Aspochalasine A, B, C und D. Helv. Chem. Acta 62: 1501 1524, 1979

2) Tomikawa, T.; K. Shin-Ya, T. Kinoshita, A. Miyajima, H. Seto \& Y. Hayakawa: Selective cytotoxicity and stereochemistry of aspochalasin D. J. Antibiotics 54: 379 381, 2001

3) Summers, M. S.; L. G. Marzilli \& A. Bax: Complete ${ }^{1} \mathrm{H}$ and ${ }^{13} \mathrm{C}$ assignments of coenzyme $\mathrm{B}_{12}$ through the use of new two-dimensional NMR experiments. J. Am. Chem. Soc. 108: 4285 4294, 1986

4) BAX, A. \& M. F. Summers: ${ }^{1} \mathrm{H}$ and ${ }^{13} \mathrm{C}$ assignments from sensitivity-enhanced detection of heteronuclear multiplebond connectivity by multiple quantum NMR. J. Am. Chem. Soc. 108: 2093 2094, 1986 